\title{
Abiotic and biotic factors influence the habitat use of an estuarine fish
}

\author{
Nathan M. Bacheler ${ }^{1,4, *}$, Lee M. Paramore ${ }^{2}$, Jeffrey A. Buckel ${ }^{1}$, \\ Joseph E. Hightower ${ }^{3}$ \\ ${ }^{1}$ Center for Marine Sciences and Technology, Department of Biology, North Carolina State University, \\ 303 College Circle Drive, Morehead City, North Carolina 28557, USA \\ ${ }^{2}$ North Carolina Division of Marine Fisheries, PO Box 539, 604 Harbor Road, Wanchese, North Carolina 27981, USA \\ ${ }^{3}$ United States Geological Survey, North Carolina Cooperative Fish and Wildlife Research Unit, Department of Biology, \\ North Carolina State University, Raleigh, North Carolina 27695, USA \\ ${ }^{4}$ Present address: College of Oceanic and Atmospheric Sciences, 104 COAS Administration Building, \\ Oregon State University, Corvallis, Oregon 97331, USA
}

\begin{abstract}
For migratory fishes that occupy multiple habitats, surveys conducted at different scales may be required to assess habitat use. We used generalized additive models (GAMs) to relate water quality, microhabitat, geographic, and temporal factors to catches of 2 age classes of subadult red drum Sciaenops ocellatus from a 6 yr fishery-independent gill net survey in North Carolina, USA. Age-1 and age-2 red drum were most often caught in shallow, nearshore waters; in some regions, both showed a preference for seagrass. Age-1 red drum were primarily captured at 2 different salinity ranges ( 0 to 5 and 20 to $30 \mathrm{psu}$ ), while age- 2 red drum abundance was not related to salinity. A smaller-scale analysis of 36 telemetered age- 2 red drum in a small tributary of the Neuse River showed a negative response to salinity, a positive response to dissolved oxygen, a dome-shaped response to prey evenness, and a positive response to total prey. Although subadult red drum can tolerate a wide variety of environmental conditions, our research suggests that they associate with both abiotic and biotic factors in very specific ways. Habitat use patterns of subadult red drum were age-, scale-, and sometimes region-dependent, highlighting the need for examining habitat use patterns of estuarine organisms at multiple life history stages and scales if generalities about how species respond to abiotic and biotic factors are sought.
\end{abstract}

KEY WORDS: Habitat use $\cdot$ Spatial distribution $\cdot$ Telemetry $\cdot$ Sciaenops ocellatus $\cdot$ Scale

\section{INTRODUCTION}

Recent loss of estuarine habitat due to human development in coastal zones has resulted in increased attention on fish habitats by governments and researchers. Concerns about severe habitat loss and degradation in estuarine environments have prompted government action at state and federal levels to identify, prioritize, and protect essential habitats for estuarine organisms (e.g. Benaka 1999, Street et al. 2005, ASMFC 2007). It has also spurred a suite of reviews on ways to develop robust methods for identifying and prioritizing 'nursery' habitats used by estuarine organisms (e.g. Beck et al. 2001, Heck et al. 2003, Dahlgren et al. 2006). There are now a variety of approaches to prioritize conservation planning in estuarine and marine environments (e.g. Stewart et al. 2003, Morris $\&$ Ball 2006). A basic understanding of the habitat use of the species of interest is required for all of these techniques.

The issue of scale is one of the most fundamental topics in ecology (Levin 1992). Relationships of species to their environment can change qualitatively with the scale of observation, so a basic understanding of a species' ecology requires study of how pattern and variability are influenced by the scale of observation. The importance of spatial scale in terrestrial ecology is now well established (Levin 1992, Ives et al. 1993, Schnei- 
der 2001, Shriner et al. 2006). For example, Shriner et al. (2006) showed that the scale of observation profoundly influenced the spatial distribution of species richness hotspots and thus conservation planning priorities. The topic of scale has also received some attention in freshwater (Essington \& Kitchell 1999, Fagan et al. 2005, Kennard et al. 2007, Wilson \& Xenopoulos 2008) and marine fish studies (Rose \& Leggett 1990, White \& Warner 2007). In contrast, estuarine finfish studies rarely deal explicitly with issues of scale.

Much research attention has been focused on the habitat requirements of early juvenile estuarine fish (Holt et al. 1983, Rooker \& Holt 1997, Rooker et al. 1998, Stunz et al. 2002), while generally neglecting late stage juveniles. For red drum Sciaenops ocellatus, a highly prized recreational estuarine fish species found along the coast of the Southeastern USA and northern Gulf of Mexico, exploitation generally occurs on late stage juveniles (i.e. ages 1 to 3 , hereafter referred to as subadults; Bacheler et al. 2008a). Therefore, understanding the habitat use patterns of subadult stages of red drum is critical. For instance, habitat use studies are needed to prioritize important habitat types for subadult red drum in North Carolina. Moreover, detailed habitat information could be used to create temporal or seasonal fishing closures to protect high densities of subadult red drum from recreational and commercial exploitation (Collins et al. 2002).

Previous research on estuarine fish habitat use has often been hampered by small spatial scope and use of single gears; this is especially true for red drum. For instance, Adams \& Tremain (2000) observed higher catches of subadult red drum at low water temperatures during a gill net survey in a single marsh creek in Florida, but other water quality variables, such as salinity and dissolved oxygen, were not significantly related to subadult red drum catch. Alternatively, Dresser \& Kneib (2007) used ultrasonic telemetry over 5 mo to show that habitat use of subadult red drum was influenced by tidal and diel cycles in a single Georgia marsh creek; fish moved into the flooded marsh at high tide during the day and back into main channel habitats at low tide or during the night. The next logical step for an improved understanding of habitat use in subadult red drum is for a study to occur at multiple spatial scales using multiple gear types to determine the validity and generality of previous work.

In this paper, we quantified habitat use of subadult red drum in Pamlico Sound and associated rivers in North Carolina using a combination of fishery-independent gill netting to address large-scale habitat use ( 1 to $100 \mathrm{~s}$ of $\mathrm{km}$ ) and ultrasonic telemetry to quantify small-scale habitat use ( $\mathrm{m}$ to $\mathrm{km}$ ). These 2 approaches allowed us to quantify small- and large-scale habitat use patterns of subadult red drum and understand the relative influence of abiotic and biotic factors in influencing habitat use. This study improves our understanding of the ways in which organisms use estuaries and how interpretations of habitat use patterns may be dependent upon the scale at which research is conducted.

\section{MATERIALS AND METHODS}

Large-scale habitat use. Pamlico Sound and associated rivers: We quantified the physical habitat that may influence large-scale habitat use patterns of red drum in Pamlico Sound, North Carolina (Fig. 1). Pamlico Sound is the second largest estuary in North America, and is an important nursery habitat for a wide array of estuarine species (Ross \& Epperly 1986). Pamlico Sound is a shallow lagoonal system (mean depth = $5 \mathrm{~m}$ ) bordered on the east by barrier islands (the Outer Banks), and on the west by mainland eastern North Carolina and multiple rivers. The Neuse, Pamlico, and Pungo Rivers drain eastern North Carolina and empty into Pamlico Sound. Currents and tides are primarily wind-driven; lunar tides only influence the sound within a few $\mathrm{km}$ of the inlets (Pietrafesa \& Janowitz 1991). A wide variety of habitats exist in Pamlico Sound and associated rivers, including seagrass and oyster reefs that are thought to be important for subadult red drum.

NCDMF gill net survey: The North Carolina Division of Marine Fisheries (NCDMF) fisheryindependent gill net survey began in Pamlico Sound in May 2001 and in the Pamlico, Neuse, and Pungo Rivers in July 2003. Five regions are considered in this study: Outer Banks, Hyde County, Neuse River, Pamlico River, and Pungo River. Sampling in the first year of the study occurred year-round, but was changed thereafter to exclude the month of January due to unsafe working conditions on the water in winter months.

Sampling locations for the gill net survey were selected using a stratified random sampling design based on strata and water depth (Fig. 1). The sound was divided into 8 strata: Hyde County 1 through 4 and Outer Banks 1 through 4. The Neuse River was divided into 4 strata (Upper, Upper-Middle, Middle-Lower, Lower) and the Pamlico River was divided into 3 strata (Upper, Middle, Lower), while the Pungo River was not divided. A $1 \times 1$ ' grid (i.e. 1 nautical mile ${ }^{2}$ ) was overlaid over all strata and each cell was classified as shallow $(<1.83 \mathrm{~m})$ or deep $(\geq 1.83 \mathrm{~m})$, or both, based on bathymetric maps.

Each stratum was sampled twice a month. One cell was randomly selected within each stratum by using the SAS procedure PLAN for each sampling occasion. If that 


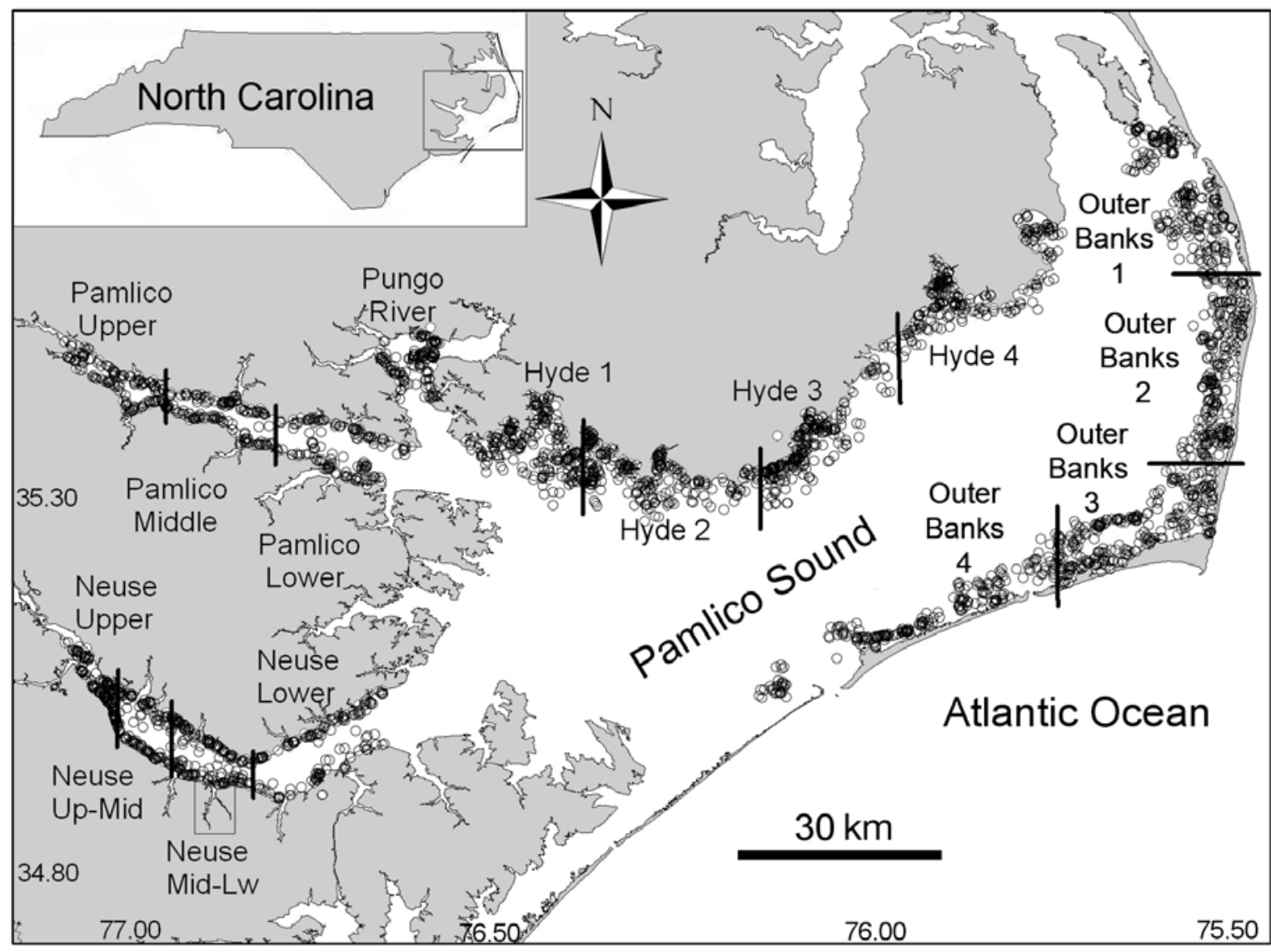

Fig. 1. Sciaenops ocellatus. Pamlico Sound and associated rivers with gill net survey sampling strata (separated from each other by thick black lines) and gill net sites (open circles) sampled between 2001 and 2006. Five regions were sampled: Outer Banks, Hyde County, Neuse River, Pamlico River, and Pungo River. Small-scale habitat use of red drum was examined in Hancock Creek, located in the Neuse Middle-Lower (Mid-Lw) stratum, and is surrounded by a box

cell had both deep and shallow habitat then both sets were made in that cell. If the cell lacked either deep or shallow water, then the closest suitable habitat in an adjacent cell was used. Sampling was conducted with a gill net consisting of eight $27.4 \mathrm{~m}$ segments of 7.6, 8.9, 10.2, $11.4,12.7,14.0,15.2$, and $16.5 \mathrm{~cm}$ stretched mesh webbing, totaling $219.5 \mathrm{~m}$ of gill net on each sampling date per cell. Shallow cells were sampled with floating gill nets and deep cells were sampled with sinking gill nets; vertical height of nets was between 1.8 and $2.1 \mathrm{~m}$ deep. Nets set along the shoreline were most typically set perpendicular to shore, whereas most deep sets (and shallow sets offshore) were typically set parallel to shore along a depth contour. Nets were typically deployed within $1 \mathrm{~h}$ of sunset and retrieved the next morning, so all soak times were approximately $12 \mathrm{~h}$. This sampling design resulted in a total of approximately 64 gill net samples $\mathrm{mo}^{-1}$.

Red drum from gill nets were enumerated, measured for fork length (mm), and released. We converted length of red drum from fork to total based on the conversion provided by Ross et al. (1995). We then used a 6 mo age- length key to convert total length of fish at capture to an estimated age based on a September 1 birth and a January 1 birthday for all additional age groups (i.e. age-0 red drum are 0 to 3 mo old, age- 1 fish are 4 to 16 mo old, and so on). The age-length key was based on $17 \mathrm{yr}$ of North Carolina red drum ageing data from otoliths (NCDMF unpubl. data); annuli were validated by Ross et al. (1995). A 6 mo age-length key (January to June and July to December) was used because of rapid summer growth rates that subadult red drum experience in North Carolina (Ross et al. 1995). The 6 mo age-length key provided very good separation of length groupings of fish until age 4 . However, catches of age-3 and older red drum were rare, so only age- 1 and age- 2 red drum were considered here. Age-dependent catch-per-unit-effort (CPUE) was calculated as the number of each age group of red drum caught in each gill net set per hour.

Habitat measurements were taken at deployment and retrieval of each gill net set, and average values were used for analyses. Temperature $\left({ }^{\circ} \mathrm{C}\right)$, salinity (psu), and dissolved oxygen $\left(\mathrm{mg} \mathrm{l}^{-1}\right)$ were measured with a YSI 85 environmental monitoring system (Yel- 
low Springs Instruments). Sediment size was classified into one of 4 categories: clay, mud, mud and sand mix, and sand. Above-bottom habitat was also visually estimated as being primarily composed of algae, detritus, seagrass, oyster shell, or none. Distance from shore was estimated with a rangefinder and categorized into one of the following bins: 0 to $99 \mathrm{~m}, 100$ to $199 \mathrm{~m}, 200$ to $299 \mathrm{~m}, 300$ to $399 \mathrm{~m}, 400$ to $499 \mathrm{~m}, 500$ to $599 \mathrm{~m}$, or greater than $599 \mathrm{~m}$. Depth (m) was determined using an onboard depth finder.

NCDMF gill net survey analyses: We used generalized additive models (GAMs) to examine the relationship between independent variables and the CPUE of red drum caught at a particular location. A GAM is a generalization of generalized linear models and its main advantage over traditional regression techniques is its capability to model nonlinearities, common in ecological studies, using nonparametric smoothed curves (Hastie \& Tibshirani 1990). GAMs replace the traditional least-squares estimate of multiple linear regression with a local smoother; here, we used the cubic spline smoother $s$. We constructed separate models for CPUE of age-1 and age-2 red drum, and assumed a Poisson error distribution with a log link function because it is recommended when the response is count data (Swartzman et al. 1992). Explanatory variables included water quality (temperature, salinity, dissolved oxygen), microhabitat (sediment size, above-bottom habitat), geographic (distance from shore, depth, region), and temporal (year, month) factors. Given likely differences in habitat availability among regions, we also constructed separate GAMs for age- 1 and age- 2 red drum within each of the 5 regions. An added benefit of region-specific GAMs is that they can be used to examine the generality of habitat use patterns of red drum in North Carolina.

A backwards-stepwise selection procedure was used to compare different ways of including each variable and to remove those terms that did not improve model fit significantly (Venables \& Ripley 1999). There were 4 possibilities for each variable: a flexible nonlinear smoothed effect with 4 degrees of freedom, a less flexible nonlinear smoothed effect with 2 degrees of freedom, a linear effect, or exclusion from the model. However, 'Region,' 'Sediment size,' and 'Above-bottom habitat' could only enter the model as categorical variables with a linear effect or be excluded. Akaike's Information Criterion (AIC) was used to select the model that provides the best fit with the fewest degrees of freedom used (Burnham \& Anderson 2002). Deviance explained by the model was approximated by subtracting residual deviance from null deviance and dividing that value by the null deviance (Stoner et al. 2001). All models were constructed and tested using the 'gam' and 'stepgam' procedures in S-PLUS 2000 (Insightful).
Red drum food habits in Hancock Creek. Hancock Creek is a lateral tributary of the lower Neuse River (Fig. 1). It is shallow (mean depth $=1.5 \mathrm{~m}$ ) and oligohaline, and is fringed by forest, marsh, and very little shoreline development. Hancock Creek is approximately $7 \mathrm{~km}$ long and at most $0.5 \mathrm{~km}$ wide. Its shallow depth $(<2 \mathrm{~m}$ throughout) and narrow width reduces the confounding influence of depth and distance offshore as predictor variables, allowing a clearer examination of how prey variables influence the habitat use of red drum.

We used stomach content analysis to identify the major prey in Hancock Creek that might influence red drum habitat use. Quarterly diet samples were taken from age-2 red drum during daylight hours $\pm 12 \mathrm{~d}$ around 1 February, 1 May, 1 August, and 1 November 2006. An additional collection of age-2 red drum occurred the previous year, on 8 June 2005, in Hancock Creek, and is included in these analyses to increase sample size of stomachs examined. Most red drum were captured using the 'strike net' method, whereby a $200 \mathrm{~m}$ gill net with $102 \mathrm{~mm}$ stretch mesh was set in an arc along the shoreline. A $7.2 \mathrm{~m}$ research vessel was then driven between the net and shoreline, scaring fish into the net. The net was immediately retrieved, and when red drum were captured, the monofilament netting was cut in order to prevent injury when removing the fish. Electrofishing was used to collect the remaining red drum. Fish were held temporarily in $140 \mathrm{l}$ aerated tanks on board the research vessel for a maximum of $1 \mathrm{~h}$ to reduce regurgitation or digestion (Sutton et al. 2004).

Gastric lavage was used to extract stomach contents from individual subadult red drum. Previous studies have shown that gastric lavage is an effective means to remove stomach contents from a variety of fishes (Crossman \& Hamilton 1978, Waters et al. 2004). The gastric lavage device was constructed based on the design described by Crossman \& Hamilton (1978) and gastric lavage protocol followed Waters et al. (2004). Briefly, a $12 \mathrm{~V}$ bilge pump $\left(1382 \mathrm{l} \mathrm{h}^{-1}\right)$ was used to flush items out of the stomach into a fine mesh net positioned under the red drum. Once no additional materials were being flushed out (approximately $45 \mathrm{~s} \mathrm{fish}^{-1}$ ), the contents from the net were placed into a plastic bag, which was then sealed, labeled, and placed on ice. Fish were then released alive, except for 4 that were sacrificed to verify the gastric lavage method. All stomach items were taken back to the laboratory and identified, sorted, measured for TL or carapace width (in the case of crabs), blotted, and weighed wet $( \pm 0.001 \mathrm{~g})$ within $24 \mathrm{~h}$ of extraction. Stomach contents of individual red drum within a quarterly sampling period were combined and summarized together in terms of frequency of occurrence (proportion of stom- 
achs with food containing a prey type) and percent by weight (proportionate contribution of identifiable prey to diet by weight).

Small-scale habitat use. Abiotic and biotic sampling in Hancock Creek: To test the influence of prey abundance and diversity on red drum distribution, we examined the fish's small-scale habitat use in Hancock Creek. Quarterly surveys of red drum distribution, potential prey items, and physicochemical characteristics were made in Hancock Creek in 2006. These surveys occurred on 1 to 2 February, 1 to 2 May, 2 to 3 August, and 30 to 31 October. Hancock Creek was divided into 20 strata of similar size, and sampling occurred in all of these 20 strata in each of the 4 seasonal periods.

Spatial and temporal patterns of habitat use of red drum were quantified using ultrasonic telemetry methods, an approach that can effectively assess the distribution and habitat use of fishes (Cooke et al. 2004). Age-2 red drum were captured using strike netting or electrofishing and placed in aerated $140 \mathrm{l}$ tanks on board a research vessel. Red drum were anesthetized individually in $20 \mathrm{l}$ aerated water in a covered cooler with $150 \mathrm{mg} \mathrm{l}^{-1}$ tricaine methanosulfonate (Finquel MS-222), measured for TL (mm), weighed ( $\mathrm{g})$, and placed dorsal side down on an open-cell foam-cushioned surgical platform fitted onto a 501 cooler equipped with a re-circulating pump. Water containing anesthetic (75 $\mathrm{mg} \mathrm{l}^{-1} \mathrm{MS}-222$ ) was then pumped over the gills at approximately $680 \mathrm{l} \mathrm{h}^{-1}$. An incision was made $4 \mathrm{~cm}$ caudal to the pelvic girdle and $5 \mathrm{~mm}$ to the right of the ventral midline.

Ultrasonic transmitters (VEMCO; V16 4H, $10 \mathrm{~g}$ in water; $10 \mathrm{~mm}$ wide; $65 \mathrm{~mm}$ long) were inserted cranially, but pulled back caudally so that the transmitter was positioned directly under the incision. The transmitters operated on a frequency of $69 \mathrm{kHz}$ and were programmed to be constantly active for a period of $641 \mathrm{~d}$. The incision was closed using a simple interrupted pattern with 3-0 PDS absorbable sutures. Fish were returned to $140 \mathrm{l}$ aerated tanks for recovery and were released at capture sites once swimming behavior had returned to normal (approximately 15 to $20 \mathrm{~min}$ ). Telemetered red drum were located monthly in 2006, but quarterly relocations in early February, May, August, and November are only included in our full Hancock Creek GAM to match up with quarterly prey data. Relocation probabilities of telemetered red drum exceeded $90 \%$ on all quarterly search occasions in Hancock Creek (Bacheler 2008). The response variable used in statistical models was the presence or absence of telemetered red drum in each stratum.

Prey densities were quantified within each stratum and sampling period using an otter trawl. The otter trawl had a $5.0 \mathrm{~m}$ headrope length, $25 \mathrm{~mm}$ bar mesh wings and body, and a $6.4 \mathrm{~mm}$ bar mesh tail bag. Bottom fauna, the main prey of subadult red drum (Scharf \& Schlicht 2000), are most reliably and efficiently collected using an otter trawl (Ross \& Epperly 1986, Rozas \& Minello 1997). Because all sampling took place in shallow water $(<2.0 \mathrm{~m})$, the net opening included the majority of the water column.

To determine the location of trawling within a stratum, each stratum was divided into $10 \times 150 \mathrm{~m}$ cells, and 1 cell stratum ${ }^{-1}$ was randomly selected within a quarterly sampling period. The trawl was towed by a $7.2 \mathrm{~m}$ research vessel at approximately $77.0 \mathrm{~m} \mathrm{~min}^{-1}$ for 2 min within the randomly selected cell in each stratum for a total of 20 trawl stations each quarter. All potential prey items (species and sizes) of red drum were enumerated, and a random sub-sample of 30 individuals of each species was measured for total length (fish or shrimp) or carapace width (crabs).

Only species and sizes of prey found in the diet of red drum were included in the model. Three prey metrics were used as independent predictors: prey richness, total prey, and the Shannon Index of prey evenness. For each trawl in a stratum, prey richness was calculated as the total number of prey species while total prey was the total number of individual prey. The Shannon Index $\left(H^{\prime}\right)$ combines the number of species and the evenness of the species in a trawl sample (Krebs 1989), and is hereafter referred to as prey evenness. Temporal diet variability was difficult to determine due to low sample sizes of stomach samples from August $(n=15)$ and November $2006(n=7)$. Therefore, prey predictor variables used in GAMs (i.e. prey richness, prey evenness, and total prey) were based on red drum diet over the entire study.

Bottom temperature, salinity, dissolved oxygen, and water clarity were sampled at the beginning and end of each trawl within a stratum and the average of both samples were used in the models. All physicochemical measurements except water clarity were sampled using a YSI-85. Water clarity was measured with a standard Secchi disk at the same locations as water quality samples were taken.

Analyses of small-scale habitat use: We analyzed the relationship between red drum presence/absence and predictor variables using binomial GAMs. Binomial GAMs (with logit link function) were used to analyze relationships in Hancock Creek because they are more appropriate than GAMs using abundance when the relocation probability of telemetered red drum is $<1$. We used both abiotic (temperature, salinity, dissolved oxygen, water clarity) and biotic (prey richness, prey evenness, and total prey) factors as predictor variables. Sample size of trawls was too small $(n=20)$ to analyze each seasonal period independently, so we included a categorical 'season' variable in the model to 
Table 1. Sciaenops ocellatus. Age- and region-specific generalized additive models for red drum abundance in North Carolina. A backwards stepwise selection procedure was used to compare 4 different forms of each variable: linear effect $\left({ }^{\mathrm{a}}\right)$, nonlinear effect with 2 degrees of freedom $\left({ }^{b}\right)$, nonlinear effect with 4 degrees of freedom $\left({ }^{c}\right)$ and terms with $p>0.05$, which were dropped from the model (ns). Dissolved oxygen and sediment size were also examined, but found to have no significant effects in any of the large-scale models. Catch-per-unit-effort (CPUE) was determined as the number of red drum per gill net set. The deviance explained (dev. expl.) by each model is also given

\begin{tabular}{|c|c|c|c|c|c|c|c|c|c|c|c|}
\hline Model & $\begin{array}{l}\text { No. of } \\
\text { sets }\end{array}$ & $\begin{array}{l}\text { Red drum } \\
\text { caught }\end{array}$ & CPUE & Depth & $\begin{array}{l}\text { Distance } \\
\text { offshore }\end{array}$ & Temp. & Salinity & $\begin{array}{l}\text { Above- } \\
\text { bottom }\end{array}$ & Year & Month & $\begin{array}{c}\text { Dev. } \\
\text { expl. (\%) }\end{array}$ \\
\hline \multicolumn{12}{|l|}{ Age-1 } \\
\hline Outer Banks & 982 & 979 & 1.00 & $<0.001^{\mathrm{a}}$ & $<0.001^{\mathrm{a}}$ & $\mathrm{ns}$ & $0.024^{\mathrm{b}}$ & $<0.001^{\mathrm{a}}$ & $<0.001^{\mathrm{c}}$ & $<0.001^{\mathrm{c}}$ & 63 \\
\hline Hyde County & 939 & 1224 & 1.30 & $<0.001^{\mathrm{a}}$ & $<0.001^{\mathrm{b}}$ & ns & ns & $<0.001^{\mathrm{a}}$ & $<0.001^{\mathrm{c}}$ & $<0.001^{\mathrm{c}}$ & 73 \\
\hline Neuse River & 551 & 1087 & 1.97 & $<0.001^{\mathrm{b}}$ & ns & $\mathrm{ns}$ & $<0.001^{\mathrm{c}}$ & ns & $<0.001^{\mathrm{c}}$ & $<0.001^{\mathrm{c}}$ & 68 \\
\hline Pamlico River & 424 & 534 & 1.26 & ns & $<0.001^{\mathrm{a}}$ & $\mathrm{ns}$ & ns & ns & $0.021^{\mathrm{c}}$ & $<0.001^{\mathrm{c}}$ & 63 \\
\hline Pungo River & 139 & 210 & 1.51 & ns & $<0.001^{\mathrm{a}}$ & $\mathrm{ns}$ & ns & ns & $0.009^{b}$ & $<0.001^{b}$ & 72 \\
\hline All regions & 3035 & 4034 & 1.33 & $<0.001^{\mathrm{b}}$ & $<0.001^{\mathrm{b}}$ & $\mathrm{ns}$ & $0.005^{c}$ & $<0.001^{\mathrm{c}}$ & $<0.001^{\mathrm{c}}$ & $<0.001^{\mathrm{c}}$ & 62 \\
\hline \multicolumn{12}{|l|}{ Age-2 } \\
\hline Outer Banks & 982 & 759 & 0.77 & $<0.001^{\mathrm{a}}$ & $\mathrm{ns}$ & $<0.001^{\mathrm{b}}$ & ns & $<0.001^{\mathrm{a}}$ & $<0.001^{\mathrm{C}}$ & $<0.001^{\mathrm{c}}$ & 46 \\
\hline Hyde County & 939 & 391 & 0.42 & ns & $<0.001^{\mathrm{a}}$ & ns & $\mathrm{ns}$ & ns & $0.025^{\mathrm{c}}$ & $<0.001^{\mathrm{a}}$ & 36 \\
\hline Neuse River & 551 & 354 & 0.64 & $<0.001^{\mathrm{a}}$ & ns & $0.002^{\mathrm{a}}$ & $<0.001^{\mathrm{a}}$ & $\mathrm{ns}$ & $<0.001^{\mathrm{c}}$ & $<0.001^{\mathrm{a}}$ & 52 \\
\hline Pamlico River & 424 & 134 & 0.32 & ns & $<0.001^{\mathrm{a}}$ & ns & ns & $\mathrm{ns}$ & $<0.001^{\mathrm{b}}$ & $<0.001^{\mathrm{b}}$ & 46 \\
\hline Pungo River & 139 & 148 & 1.06 & $<0.001^{\mathrm{a}}$ & $\mathrm{ns}$ & $\mathrm{ns}$ & $\mathrm{ns}$ & $\mathrm{ns}$ & $<0.001^{\mathrm{c}}$ & $\mathrm{ns}$ & 52 \\
\hline All regions & 3035 & 1786 & 0.59 & $<0.001^{\mathrm{b}}$ & $0.016^{\mathrm{b}}$ & $<0.001^{\mathrm{b}}$ & $\mathrm{ns}$ & $<0.001^{\mathrm{c}}$ & $<0.001^{\mathrm{c}}$ & $<0.001^{\mathrm{c}}$ & 44 \\
\hline
\end{tabular}

account for any potential differences in the numbers of telemetered red drum present during each seasonal period. An added benefit of developing a year-round model is consistency with the gill net survey yearround sampling and analyses described earlier; a drawback is that we could not examine seasonal habitat use patterns.

We were concerned that quarterly sampling in Hancock Creek was not sufficient to provide a useful comparison with the nearly year-round sampling that occurred in the Pamlico Sound gill netting component of our study. To provide more consistency with largescale GAM, we created an additional GAM model (binomial distribution, logit link function) that related the monthly (January to December, 2006) presence or absence of telemetered red drum in Hancock Creek to physicochemical parameters only (temperature, salinity, and dissolved oxygen), since prey information on a monthly scale was lacking.

\section{RESULTS}

\section{Large-scale habitat use}

Overall, 5961 red drum were caught in the Pamlico Sound gill net survey between 2001 and 2006, ranging in size from 146 to $1341 \mathrm{~mm}$ total length $(424.0 \pm 1.6$, mean $\pm \mathrm{SE})$. More age-1 red drum $(\mathrm{n}=4034$; $\mathrm{CPUE}=$ 1.33) were caught than age- 2 fish $(\mathrm{n}=1786$; $\mathrm{CPUE}=$ 0.59). Age-1 red drum were widely distributed from the upper reaches of the Neuse and Pamlico Rivers all the way to behind the Outer Banks. Age-2 red drum were also widely distributed, but were more often caught in higher salinity (Outer Banks) compared to lower salinity waters (Pamlico and Neuse Rivers).

There were differences in habitat use for age- 1 and age-2 red drum (Table 1). The overall statewide age-1 GAM regression explained $62 \%$ of the variation in CPUE (Table 1). Depth, distance offshore, salinity, year, and month had significant nonlinear effects, and above-bottom habitat and region had significant linear effects, on the distribution of age-1 red drum (Table 1). Age-1 red drum were strongly associated with nearshore shallow water habitats (Fig. 2). The relationship of age-1 red drum CPUE to salinity was bimodal, with highest CPUE at low or high salinities (0 to 5 or 20 to $30 \mathrm{psu}$, respectively) and lowest catches were observed at moderate salinities (10 to $15 \mathrm{psu}$ ). Age-1 red drum CPUE was also highest in above-bottom habitat of algae, detritus, and shell, while catches were lower in sets with seagrass and no above-bottom habitat. Annual variability in CPUE was apparent; highest CPUE was observed in 2004 and 2005, and lowest was observed in 2001 (Fig. 2). There was also a strong seasonal pattern in CPUE, which peaked in late fall.

We also constructed separate GAMs for age-1 red drum in each of the 5 regions to examine possible regional habitat use differences (Table 1). Regionalspecific age-1 GAMs explained 63 to $73 \%$ of the deviance, and were generally consistent in the variables that were included in the models. For instance, 3 of 5 regional models included depth, 4 of 5 models included distance offshore, and all 5 included year and 
month effects. Regional effects of these 4 variables were similar to overall statewide trends. In contrast, 2 variables had regionally dependent effects: salinity was significant in the Outer Banks and Neuse River only, and above-bottom habitat was significant in the Outer Banks and Hyde Counties only. Higher catches of red drum were associated with seagrass, and to a lesser extent shell bottom, in the Outer Banks, while age-1 red drum in Hyde County were more strongly associated with algae and detritus.
Age-1 red drum were related to salinity in different ways in the Neuse River and Outer Banks regions (Fig. 3). In the oligohaline Neuse River, age-1 red drum were associated with the lowest salinities $(<5 \mathrm{psu})$, and were found less commonly in higher salinity waters. In contrast, age-1 red drum in the Outer Banks were observed in salinities of $\sim 20$ psu or higher and CPUE decreased at lower salinities. The regional differences in the response of age- 1 red drum to salinity observed in the Neuse River and Outer Banks appeared to
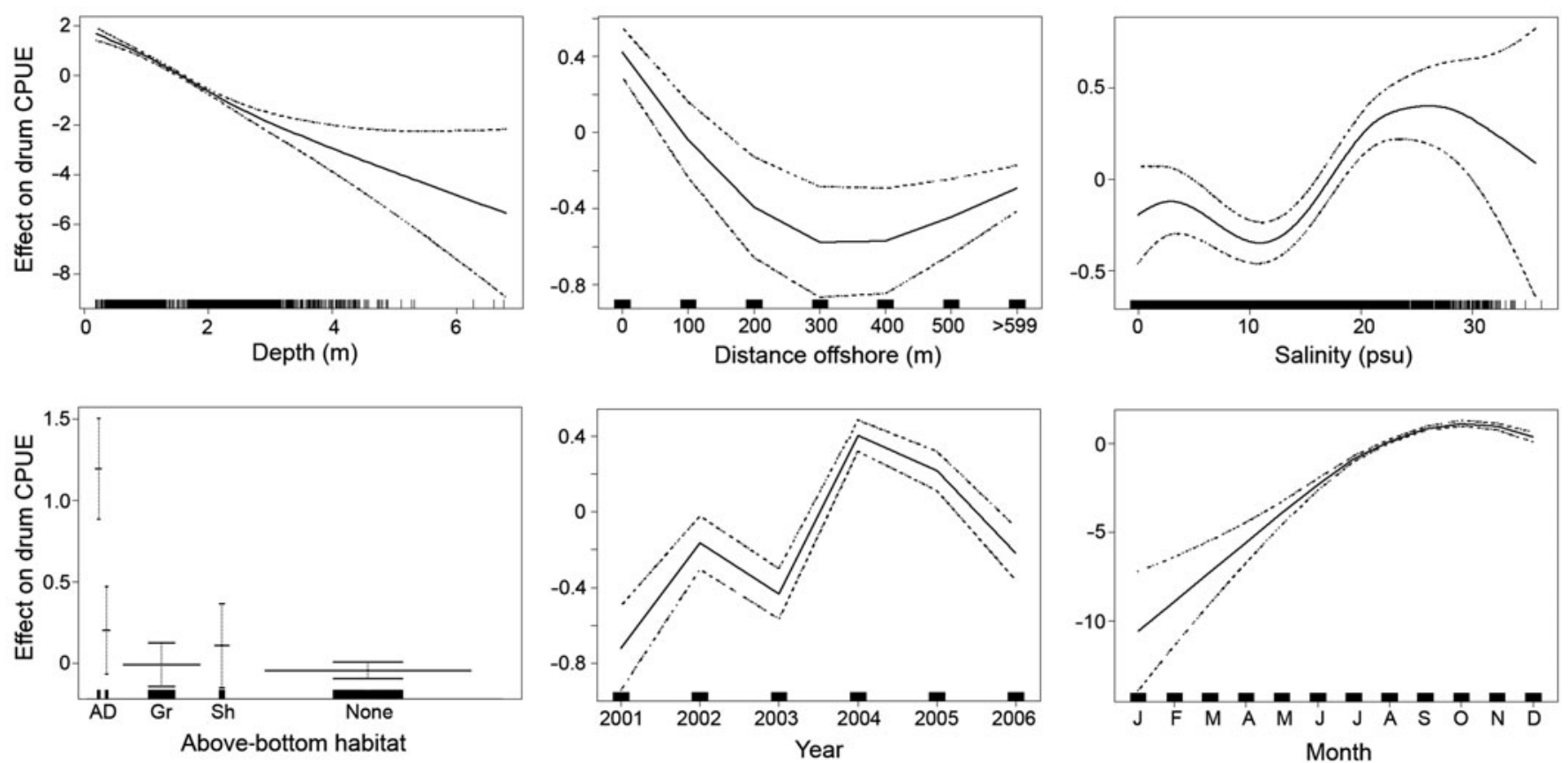

Fig. 2. Sciaenops ocellatus. Cubic spline smoothed generalized additive model plots of the effects of physical habitat features on the abundance of age-1 red drum captured in the NCDMF gill net survey, 2001-2006. Categories of above-bottom habitat are algae (A), detritus (D), seagrass (Gr), and oyster shell (Sh); width of bars represents sample size. Only significant factors (p $\leq 0.05$ ) are shown. The $y$-axis is the effect of the given variable on red drum abundance, and the tick marks on the $x$-axis indicate sampling intensity. Dashed lines are $2 \mathrm{SE}$
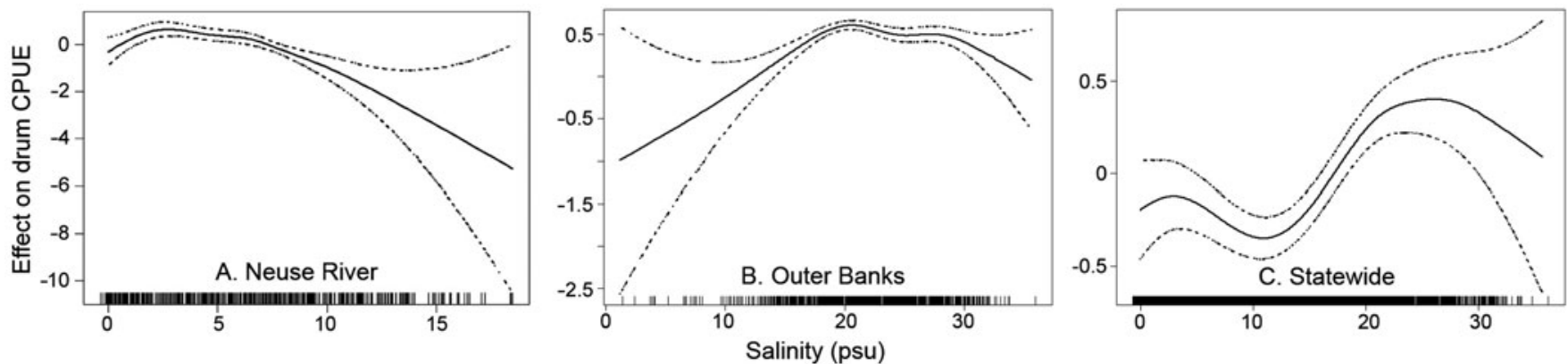

Fig. 3. Sciaenops ocellatus. Cubic spline smoothed generalized additive model plots of the effects of salinity on the abundance of age-1 red drum captured in the NCDMF gill net survey, 2001-2006. The (A) oligohaline Neuse River and (B) polyhaline Outer Banks regions are shown, in addition to the $(\mathrm{C})$ overall statewide response of age-1 red drum to salinity. The $y$-axis is the effect of the given variable on red drum abundance and the tick marks on the $x$-axis indicate sampling intensity. Dashed lines are $2 \mathrm{SE}$ 

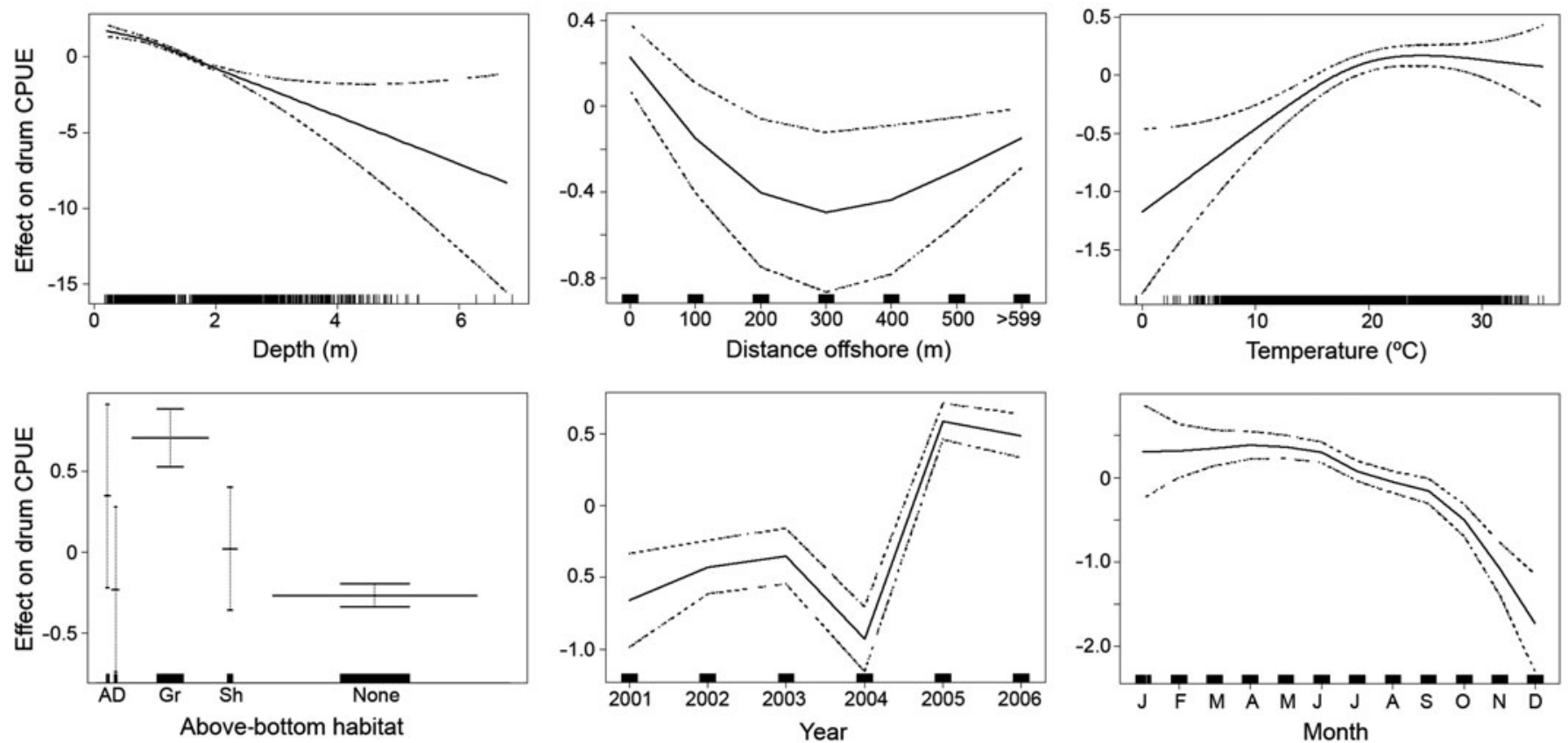

Fig. 4. Sciaenops ocellatus. Cubic spline smoothed generalized additive model plots of the effects of physical habitat features on the abundance of age-2 red drum captured in the NCDMF gill net survey, 2001-2006. Categories of above-bottom habitat are algae (A), detritus (D), seagrass (Gr), and oyster shell (Sh); width of bars represents sample size. Only significant factors ( $\mathrm{p} \leq 0.05$ ) are shown. The $y$-axis is the effect of the given variable on red drum abundance and the tick marks on the $x$-axis indicate sampling intensity. Dashed lines are $2 \mathrm{SE}$

compose the overall statewide bimodal relationship (Fig. 3).

The statewide age-2 red drum GAM regression explained $44 \%$ of the variation in CPUE, and included depth, distance offshore, temperature, above-bottom habitat, year, month, and region as predictor variables (Table 1; Fig. 4). Age-2 red drum were found most often in shallow, warm, nearshore waters associated with seagrasses. The CPUE of age- 2 red drum was also highest in 2005 and 2006, primarily during the winter, spring, and early summer months.

Regional-specific GAMs for age-2 red drum were somewhat less consistent and explained moderately less deviance than those for age-1 red drum (Table 1). Age-2 GAMs explained between 36 and $52 \%$ of the deviance in red drum CPUE. Depth, distance offshore, temperature, salinity, above-bottom habitat, year, and month were included in various regional models. In all cases, the magnitude and slope of regional responses were similar to the overall statewide response. Above-bottom habitat was only significant in the Outer Banks, showing a strong positive relationship of age-2 red drum to seagrass; preferences of seagrass by red drum in the Outer Banks was likely driving the overall statewide trend because abovebottom habitat was not selected in any other regional model.

\section{Red drum food habits in Hancock Creek}

A total of 212 age-2 red drum stomachs were examined from 2005 and 2006 collections in Hancock Creek (Table 2). No additional stomach contents were found in the 4 sacrificed red drum examined after gastric lavage was performed; thus, the likelihood of undetected prey in the released red drum was low. Across all sampling periods, $31 \%$ of red drum had empty stomachs. Invertebrate prey dominated the diet of red drum in all sampling periods except February 2006, when fish prey was slightly more important using percent by weight.

The dominant prey of red drum in Hancock Creek was blue crab Callinectes sapidus, found in 25 to $89 \%$ of stomachs during all 5 sampling periods and making up approximately half to nearly all of the diet by weight in 3 out of 5 samples (Table 2). Other important invertebrate prey included white-fingered mud crabs Rhithropanopeus harrisii, amphipods Gammarus spp., White River crayfish Procambarus acutus, and grass shrimp Palaemonetes pugio. Fish prey were also important, occurring in 22 to $100 \%$ of stomach samples within a season. Species of prey fish varied substantially among sampling periods, with southern flounder Paralichthys lethostigma, silver perch Bairdiella chrysoura, American eel Anguilla rostrata, Atlantic men- 
Table 2. Sciaenops ocellatus. Stomach contents of age-2 red drum from Hancock Creek in the lower Neuse River, North Carolina, 2005-2006. Red drum were collected by strike netting or electroshocking and stomach contents were removed by gastric lavage. $\%$ F: proportion of stomachs with food containing a particular prey type, \%W: proportion of identifiable prey types to overall stomach contents by weight

\begin{tabular}{|c|c|c|c|c|c|c|c|c|c|c|}
\hline \multirow[t]{2}{*}{ Prey type } & \multicolumn{2}{|c|}{ Jun 2005} & \multicolumn{2}{|c|}{ Feb 2006} & \multicolumn{2}{|c|}{ May 2006} & \multicolumn{2}{|c|}{ Aug 2006} & \multicolumn{2}{|c|}{ Nov 2006} \\
\hline & $\% \mathrm{~F}$ & $\% \mathrm{~W}$ & $\% \mathrm{~F}$ & $\% \mathrm{~W}$ & $\% \mathrm{~F}$ & $\% \mathrm{~W}$ & $\% \mathrm{~F}$ & $\% \mathrm{~W}$ & $\% \mathrm{~F}$ & $\% \mathrm{~W}$ \\
\hline \multicolumn{11}{|l|}{ Invertebrates } \\
\hline Blue crab & 30.4 & 45.1 & 24.5 & 7.9 & 64.5 & 58.1 & 88.9 & 95.4 & 33.3 & 1.1 \\
\hline Mud crab & & & 4.1 & 2.0 & 38.7 & 9.6 & 11.1 & $<0.1$ & 33.3 & 0.8 \\
\hline Amphipoda & 4.3 & $<0.1$ & 71.4 & 11.9 & 8.1 & $<0.1$ & & & & \\
\hline White River crayfish & 13.0 & 29.4 & 2.0 & 5.2 & 9.7 & 3.6 & & & & \\
\hline Grass shrimp & & & 16.3 & 5.0 & 21.0 & 4.0 & & & & \\
\hline Brown shrimp & & & 2.0 & 4.6 & & & 11.1 & 0.5 & & \\
\hline Cyathura & & & 6.1 & 0.2 & & & & & & \\
\hline Dragonfly larvae & & & & & 3.2 & 2.8 & & & & \\
\hline Isopoda & & & & & 1.6 & $<0.1$ & & & & \\
\hline Damselfly larvae & & & & & 1.6 & $<0.1$ & & & & \\
\hline Unid. invertebrates & 4.3 & 0.7 & 2.0 & 0.7 & & & & & & \\
\hline Total invertebrates & 52.2 & 75.2 & 128.5 & 37.5 & 148.4 & 78.1 & 111.1 & 95.9 & 66.7 & 1.9 \\
\hline \multicolumn{11}{|l|}{ Fish } \\
\hline Southern flounder & 8.7 & 8.5 & & & 6.5 & 2.4 & & & 33.3 & 47.9 \\
\hline Silver perch & & & & & 1.6 & 8.3 & & & 33.3 & 42.3 \\
\hline American eel & 4.3 & 0.1 & & & 6.5 & 1.7 & & & 33.3 & 7.9 \\
\hline Atlantic menhaden & 13.0 & 2.3 & 14.3 & 16.7 & & & & & & \\
\hline Lepomis spp. & & & 8.2 & 16.2 & 4.8 & 0.4 & & & & \\
\hline Bay anchovy & & & 4.1 & 1.9 & & & & & & \\
\hline Naked goby & 8.7 & 0.7 & 2.0 & 0.5 & 1.6 & $<0.1$ & & & & \\
\hline Inland silverside & & & & & 1.6 & 0.2 & & & & \\
\hline Atlantic croaker & & & & & 1.6 & 0.1 & & & & \\
\hline Unidentified fish & 60.9 & 9.4 & 12.2 & 14.6 & 12.9 & 1.4 & 22.2 & $<0.1$ & & \\
\hline Total fish & 95.7 & 21.0 & 40.8 & 49.9 & 37.1 & 14.6 & 22.2 & $<0.1$ & 100.0 & 98.1 \\
\hline Other $^{\mathrm{a}}$ & 30.4 & 3.8 & 79.6 & 12.6 & 59.4 & 7.3 & 66.7 & 3.8 & & \\
\hline Total stomachs analyzed & \multicolumn{2}{|c|}{25} & \multicolumn{2}{|c|}{74} & \multicolumn{2}{|c|}{91} & \multicolumn{2}{|c|}{15} & \multicolumn{2}{|c|}{7} \\
\hline Number containing prey & \multicolumn{2}{|c|}{23} & \multicolumn{2}{|c|}{49} & \multicolumn{2}{|c|}{62} & \multicolumn{2}{|c|}{9} & \multicolumn{2}{|c|}{3} \\
\hline Mean TL (mm) (SE) & \multicolumn{2}{|c|}{$467.3(5.8)$} & \multicolumn{2}{|c|}{$438.8(3.9)$} & \multicolumn{2}{|c|}{$441.3(3.4)$} & \multicolumn{2}{|c|}{$515.6(8.4)$} & \multicolumn{2}{|c|}{$503.4 \quad(48.1)$} \\
\hline TL range (mm) & \multicolumn{2}{|c|}{$425-507$} & \multicolumn{2}{|c|}{$360-509$} & \multicolumn{2}{|c|}{$385-568$} & \multicolumn{2}{|c|}{$450-582$} & 318 & 650 \\
\hline Mean wt (g) (SE) & 976. & (39.6) & 843.8 & $(17.4)$ & 854.8 & $(15.3)$ & 1190. & $(37.8)$ & 1464 & $(377.4)$ \\
\hline
\end{tabular}

haden Brevoortia tyrannus, pumpkinseed Lepomis gibbosus, and naked goby Gobiosoma bosc either contributing substantially to overall diet or occurring in at least 3 out of 5 sampling periods (Table 2).

\section{Small-scale habitat use}

Thirty-six age-2 red drum were surgically implanted with transmitters, released, and relocated at least 1 time alive during quarterly sampling in Hancock Creek (Table 3). More red drum were relocated in February $(\mathrm{n}=21)$ and May $(\mathrm{n}=21)$ than in August $(\mathrm{n}=9)$ or November $(\mathrm{n}=7)$. Individual red drum were relocated between 1 and 4 seasonal periods (Table 3); we assumed that the lack of independence did not bias results, given that over half of the fish
(19 out of 36) were only relocated in 1 seasonal period and only 4 fish were relocated more than 2 times.

Significant correlations $(p<0.05)$ were present between some pairs of explanatory variables in Hancock Creek. Dissolved oxygen was negatively correlated with temperature $(\mathrm{r}=-0.91)$ and salinity $(\mathrm{r}=$ -0.69 ), and temperature and salinity were positively correlated $(r=0.76)$. Among the prey predictor variables, prey richness was positively correlated with prey evenness $(r=0.63)$ and total prey $(r=0.48)$. All remaining pairs of explanatory variables (16 out of 21) had $\mathrm{r}<0.30$. Colinearities were not deemed numerous enough to drop variables from the Hancock Creek GAM, but care was taken when interpreting results in the case that more than 1 correlated predictor variable was related to red drum (see 'Discussion'). 
Table 3. Sciaenops ocellatus. Information on 36 age-2 red drum with ultrasonic transmitters used to quantify habitat use in Hancock Creek, North Carolina, in 2006. Fish listed below were relocated in at least 1 quarterly relocation period (denoted by an ' $\mathrm{X}$ '): February, May, August, or November

\begin{tabular}{|c|c|c|c|c|c|c|c|}
\hline \multirow{2}{*}{$\begin{array}{l}\text { Fish } \\
\#\end{array}$} & \multirow{2}{*}{$\begin{array}{l}\text { Surgery } \\
\text { date }\end{array}$} & \multirow{2}{*}{$\begin{array}{c}\mathrm{TL} \\
(\mathrm{mm})\end{array}$} & \multirow{2}{*}{$\begin{array}{l}\text { Weight } \\
\text { (g) }\end{array}$} & \multicolumn{4}{|c|}{ Sampling period relocated } \\
\hline & & & & Feb & May & Aug & Nov \\
\hline \multicolumn{8}{|l|}{2005} \\
\hline 1 & $21 \mathrm{Mar}$ & 468 & 890 & $\mathrm{X}$ & $\mathrm{X}$ & & \\
\hline 2 & 21 Mar & 447 & 875 & $\mathrm{X}$ & $X$ & $X$ & \\
\hline 3 & 25 Mar & 445 & 465 & $\mathrm{X}$ & & & \\
\hline 4 & 25 Mar & 452 & 929 & $\mathrm{X}$ & $\mathrm{X}$ & & \\
\hline 5 & $28 \mathrm{Nov}$ & 459 & 1075 & $\mathrm{X}$ & & & \\
\hline 6 & $28 \mathrm{Nov}$ & 444 & 926 & $\mathrm{X}$ & & & \\
\hline 7 & $28 \mathrm{Nov}$ & 471 & 1071 & $\mathrm{X}$ & & & \\
\hline 8 & $28 \mathrm{Nov}$ & 456 & 807 & $\mathrm{X}$ & $X$ & & \\
\hline 9 & $28 \mathrm{Nov}$ & 431 & 867 & $\mathrm{X}$ & $\mathrm{X}$ & $\mathrm{X}$ & $\mathrm{X}$ \\
\hline 10 & $28 \mathrm{Nov}$ & 456 & 888 & $\mathrm{X}$ & $X$ & & \\
\hline 11 & $28 \mathrm{Nov}$ & 452 & 969 & $\mathrm{X}$ & $\mathrm{X}$ & & \\
\hline 12 & $28 \mathrm{Nov}$ & 453 & 1011 & $\mathrm{X}$ & & & \\
\hline 13 & $28 \mathrm{Nov}$ & 416 & 849 & $\mathrm{X}$ & & & \\
\hline 14 & $28 \mathrm{Nov}$ & 449 & 841 & $\mathrm{X}$ & & & \\
\hline 15 & $28 \mathrm{Nov}$ & 428 & 872 & $\mathrm{X}$ & & & \\
\hline 16 & $28 \mathrm{Nov}$ & 445 & 1025 & $\mathrm{X}$ & & & \\
\hline \multicolumn{8}{|c|}{2006} \\
\hline 17 & 24 Jan & 437 & 863 & $\mathrm{X}$ & & & \\
\hline 18 & 24 Jan & 453 & 899 & $\mathrm{X}$ & $\mathrm{X}$ & & $\mathrm{X}$ \\
\hline 19 & 24 Jan & 452 & 931 & $\mathrm{X}$ & & & \\
\hline 20 & 24 Jan & 445 & 821 & $\mathrm{X}$ & $\mathrm{X}$ & & \\
\hline 21 & 24 Jan & 491 & 1112 & $\mathrm{X}$ & X & & \\
\hline 22 & 26 Apr & 450 & 893 & & $X$ & $X$ & $X$ \\
\hline 23 & 26 Apr & 443 & 896 & & $\mathrm{X}$ & & \\
\hline 24 & 26 Apr & 445 & 858 & & $X$ & & \\
\hline 25 & 26 Apr & 441 & 815 & & $\mathrm{X}$ & & \\
\hline 26 & 26 Apr & 442 & 870 & & $\mathrm{X}$ & & \\
\hline 27 & $27 \mathrm{Apr}$ & 458 & 935 & & $\mathrm{X}$ & & \\
\hline 28 & 27 Apr & 430 & 819 & & $\mathrm{X}$ & & \\
\hline 29 & 27 Apr & 481 & 1058 & & $X$ & & \\
\hline 30 & $27 \mathrm{Apr}$ & 457 & 985 & & $\mathrm{X}$ & $\mathrm{X}$ & \\
\hline 31 & 27 Apr & 447 & 991 & & $X$ & & \\
\hline 32 & $27 \mathrm{Apr}$ & 468 & 896 & & $\mathrm{X}$ & $\mathrm{X}$ & \\
\hline 33 & 21 Jun & 446 & 907 & & & $X$ & $X$ \\
\hline 34 & 21 Jun & 458 & 975 & & & $\mathrm{X}$ & $\mathrm{X}$ \\
\hline 35 & 21 Jun & 467 & 1027 & & & $\mathrm{X}$ & $\mathrm{X}$ \\
\hline 36 & 21 Jun & 532 & 1463 & & & $\mathrm{X}$ & $\mathrm{X}$ \\
\hline
\end{tabular}

The full GAM constructed for Hancock Creek explained $32 \%$ of the deviance and included salinity, dissolved oxygen, prey evenness, and total prey in the model (Table 4). Telemetered red drum were more often found in lower salinity waters with high dissolved oxygen (Fig. 5). They occurred more often at sites with moderate prey evenness and higher CPUE of total prey. The monthly Hancock Creek GAM ( $\mathrm{n}=36$ fish; $\mathrm{n}=156$ relocations) using temperature, salinity, and dissolved oxygen only supported quarterly results by including only salinity $(p=0.03)$ and dissolved oxygen $(p=0.04)$ as predictor variables, but it explained much less of the deviance $(13 \%)$ than the quarterly GAM that included prey information in addition to water quality parameters.
Table 4. Sciaenops ocellatus. Generalized additive models relating the presence of telemetered age-2 red drum to abiotic and biotic explanatory variables in Hancock Creek, North Carolina. A backwards stepwise selection procedure was used to compare 4 different forms of each variable: a linear effect, a nonlinear effect with 2 degrees of freedom $\left({ }^{a}\right)$, a nonlinear effect with 4 degrees of freedom $\left({ }^{b}\right)$, or exclusion from the model (terms with $\mathrm{p}>0.05$ )

\begin{tabular}{|lccrr|}
\hline Parameter & Type of effect & df & $F$ & $\operatorname{Pr}(F)$ \\
\hline Deviance explained $=\mathbf{3 2} \%$ & & & \\
Salinity & Nonlinear $^{\mathrm{a}}$ & 2.9 & 8.33 & 0.035 \\
$\begin{array}{l}\text { Dissolved oxygen } \\
\text { Linear }\end{array}$ & 1.0 & 10.21 & 0.002 \\
Prey evenness & Nonlinear $^{\mathrm{b}}$ & 0.9 & 4.76 & 0.026 \\
Total prey & Linear & 1.0 & 4.84 & $<0.001$ \\
\hline
\end{tabular}

\section{DISCUSSION}

\section{Habitat use of red drum}

We analyzed data from 2 independent gears over several years and areas using robust experimental designs to provide a comprehensive examination of habitat use for an estuarine fish. Previous work on estuarine fish habitat use has generally documented broad tolerances for water quality conditions and microhabitat (Craig \& Crowder 2000). While red drum appear to be able to tolerate a wide variety of environmental conditions (Buckley 1984, Reagan 1985, Wenner 1992, Procarione \& King 1993, Adams \& Tremain 2000), we observed specific and consistent associations with various water quality, microhabitat, geographic, and prey variables in North Carolina. In some instances, preferences for these factors differed between age- 1 and age- 2 red drum.

The GAMs we constructed explained a large amount of deviance in red drum CPUE and presence/absence (32 to $62 \%$ ), similar to or better than previous studies using GAMs to explain the spatial distribution of estuarine organisms. For instance, the annual GAMs developed by Jensen et al. (2005) described 10 to $50 \%$ of the deviance in winter distribution of mature female blue crabs in relation to environmental factors in Chesapeake Bay. The large amount of deviance explained in our study is at least partially attributable to a robust experimental design. The gill netting component had a broad spatial and temporal scope, which provided high contrast in explanatory variables, and was stratified by depth and region of the state; the telemetry component included a large sample size of telemetered fish, occurred in 4 different seasons, and was stratified by area.

Depth and distance from shore are generally regarded as 2 important determinants of habitat use 

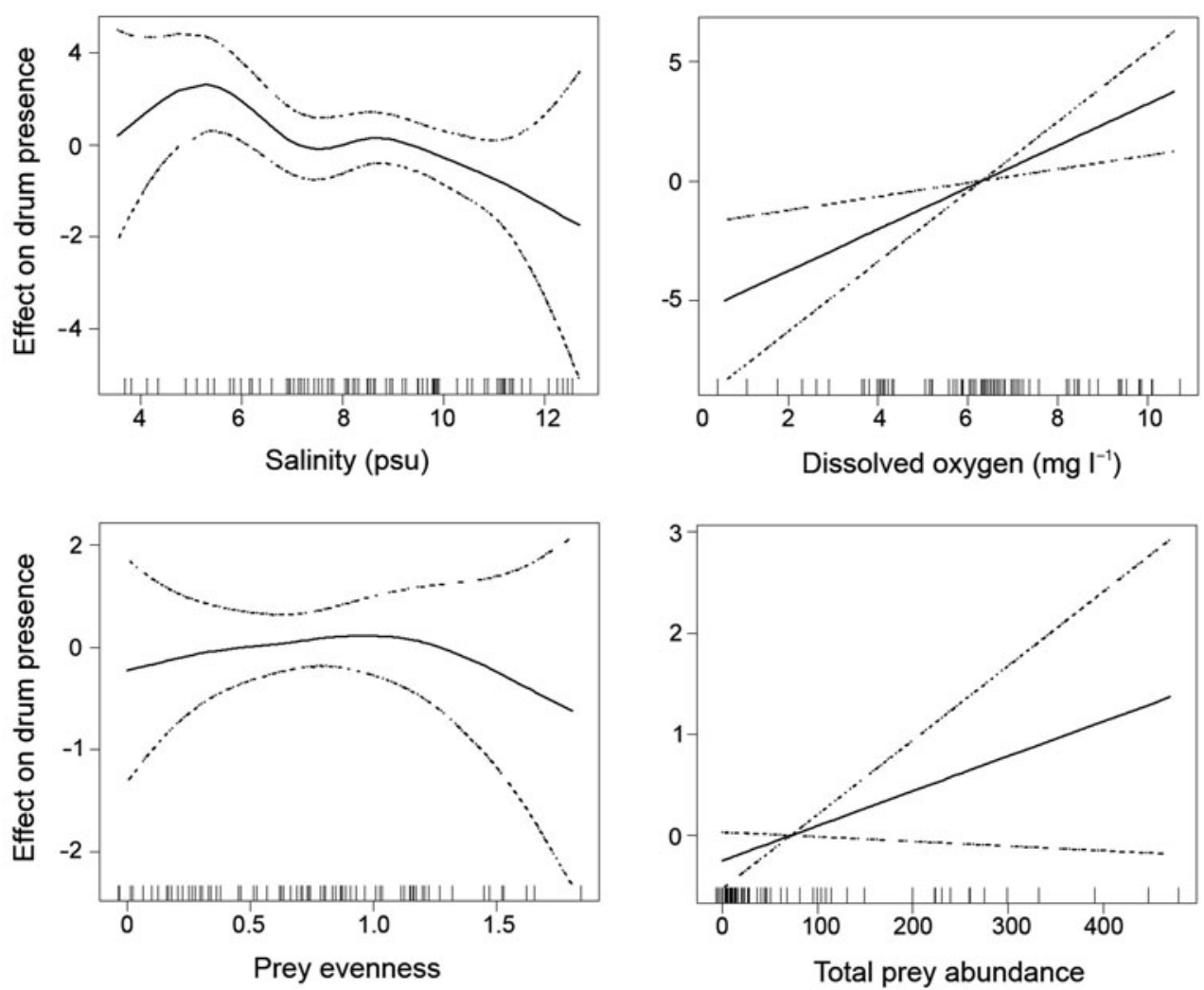

Fig. 5. Sciaenops ocellatus. Cubic spline smoothed generalized additive model plots of the effect of water quality and prey variables on the presence of telemetered age-2 red drum in Hancock Creek, North Carolina, 2006. Only significant factors ( $\mathrm{p} \leq 0.05$ ) are shown. The $y$-axis is the effect of the given variable on red drum presence and the tick marks on the $x$-axis indicate sampling intensity. Dashed lines are $2 \mathrm{SE}$

for estuarine organisms (Miltner et al. 1995, Jensen et al. 2005). Likewise, these 2 variables were the most dominant explanatory variables for the spatial distribution of age- 1 and age- 2 red drum in the gill net survey. However, these 2 predictor variables were correlated (and the only case of colinearities being included in the large-scale model), so it was impossible in our study to distinguish if subadult red drum were responding to depth or distance from shore, or both. Shallow, nearshore areas may provide subadult red drum with increased foraging opportunities (Ross \& Epperly 1986, Ruiz et al. 1993, Miltner et al. 1995, Craig \& Crowder 2000). It may also minimize predation because predators of red drum (e.g. bottlenose dolphins Tursiops truncatus) primarily occur in deeper waters in North Carolina (Gannon 2003). Further work with telemetry in areas that bottlenose dolphins frequent may help determine how subadult red drum balance feeding and predation risk (Gilliam \& Fraser 1987).

The response of organisms to estuarine water quality variables can be complex (Eby \& Crowder 2002, Bell et al. 2003). In the present study, there was a positive relationship between age- 2 red drum and tempera- ture, but only in the Neuse River and Outer Banks regions. This response to temperature was most likely not a matter of selection of the warmest available water, but instead relates to the higher seasonal abundance of age-2 red drum in spring and summer. We did not observe increased CPUE of red drum in response to cooler water temperatures as was noted in Indian River, Florida (Adams \& Tremain 2000), but the broader spatial examination of habitat use in our study may explain this inconsistency.

Despite previous research showing salinity to be the major factor in structuring estuarine fish distributions (Barletta et al. 2005), subadult red drum in our study displayed a variable response to salinity. The selection of the lowest and highest salinities by age-1 red drum in our study may be due to the physiological requirements of these fish, but more research is needed to disentangle direct effects of salinity from other covarying factors such as prey or predator distribution. In addition, because salinity and dissolved oxygen were covarying predictor variables, their inclusion in the Hancock Creek GAM should be viewed cautiously.

The effects of hypoxia (i.e. areas with dissolved oxygen concentration $<2 \mathrm{mg} \mathrm{l}^{-1}$ ) on fishes are well docu- 
mented, often resulting in behavioral avoidance or reduced growth or survival (Pihl et al. 1991, Eby \& Crowder 2002). We did not observe significant effects of dissolved oxygen concentration on the distribution of either age class of red drum from the gill net survey, but subadult red drum CPUE was positively related to dissolved oxygen levels in Hancock Creek. The response of red drum to hypoxic waters may not have been well quantified in the gill net portion of our study because hypoxic waters were documented at less than $1 \%$ of all gill net sets. In contrast, small-scale sampling in Hancock Creek revealed a strong response of subadult red drum to dissolved oxygen, perhaps because telemetry can detect the fine-scale habitat use patterns that may have been changing over the course of minutes or hours (e.g. Bell et al. 2003).

Seagrass is known to be important for a variety of estuarine organisms (Heck et al. 2003, Minello et al. 2003). Although all stages of red drum have been documented in seagrass beds, there is a lack of information on the selection or avoidance of seagrasses by subadult red drum. The use of seagrass by red drum in the Outer Banks only may be related to its abundance, since the Outer Banks has by far the highest amount of seagrass of any region in North Carolina (Street et al. 2005). Alternatively, red drum may only associate with certain species of seagrass that only occur in the polyhaline waters of the Outer Banks, such as eelgrass Zostera marina or shoalgrass Halodule wrightii. Our conclusions regarding selection of seagrass would have been more decisive if we had the resources to use telemetry in polyhaline waters as we did in Hancock Creek.

There was significant annual variation in the CPUE of age- 1 and age- 2 red drum over the period from 2001 to 2006 observed in all regions. Furthermore, there was reasonably good agreement of age-1 CPUE with age-2 CPUE the following year (e.g. high value for age-1 red drum in 2004 and age-2 red drum in 2005). Variation in year-class strength resulting from processes in the early life history of red drum likely drove these yearly differences in CPUE (Bacheler et al. 2008b). High variability in red drum year class strength has also been observed in South Carolina (Wenner 1992) and Texas (Scharf 2000).

Monthly trends in CPUE for age-1 and age-2 red drum likely represented a combination of changing gear selectivity, migratory behavior, and fishery removals. Age-1 red drum in winter and spring were too small to be sampled by the smallest mesh of the experimental gill nets $(7.6 \mathrm{~cm})$, but selectivity slowly increased throughout the year as red drum increased in size until catches reached the highest levels in the fall months. Monthly CPUE of age-2 fish was high in winter, spring, and summer months, but decreased in the fall. Decreased CPUE in fall months for age-2 red drum was likely due to a combination of removals of age-2 fish from intense fishing (Takade \& Paramore 2007) and reduced selectivity of larger fish that begin to associate with inlets or other habitats not sampled in this study (Bacheler et al. 2008a).

Estuarine habitat studies have often focused on the role of abiotic factors in determining habitat use of estuarine organisms (e.g. Pietrafesa et al. 1986, Whitfield 1996, Baltz \& Jones 2003), while often neglecting the role of prey distribution (see Craig \& Crowder 2000 for a review). However, the distribution of prey has been a major determinant of estuarine fish habitat use in the limited situations where it has been examined (e.g. McIvor \& Odum 1988, Miltner et al. 1995, Alofs \& Polivka 2004). By examining habitat use of red drum using telemetry in a non-tidal system such as Hancock Creek, we were able to show a clear response of subadult red drum to total prey. Diet of red drum in our study was diverse, as observed in prior studies (e.g. Scharf \& Schlicht 2000), so total prey was used instead of focusing on a single prey type. Previous work found no significant overlap of age-1 red drum with their prey in a tidal salt marsh system in Georgia (Dresser 2003). However, the complicated movement patterns of red drum in Georgia (i.e. movement influenced by tides and time of day) and limited prey sampling may have obscured the true relationship of red drum to prey organisms (Dresser 2003, Dresser \& Kneib 2007).

\section{Importance of scale}

Three abiotic explanatory variables (temperature, salinity, and dissolved oxygen) were examined in both our large-scale and small-scale assessments and could be used to understand whether red drum habitat use was scale-dependent. Most notably, the effect of salinity on age-1 red drum habitat use appeared to be dependent upon the scale at which research was conducted; had we limited our sampling to the Neuse River (or Hancock Creek), we would have concluded that subadult red drum habitat use was negatively correlated to salinity. At the larger scale of Pamlico Sound (100s of $\mathrm{km})$, however, we observed a bimodal relationship of red drum CPUE to salinity. Age-1 red drum showed nearly an identical response to salinity from the Neuse River gill netting and the Hancock Creek telemetry, suggesting that red drum's response was indeed scale-dependent and not a result of the methodological differences between the 2 types of data.

Our results are consistent with previous work on the scale-dependency of habitat use and suggest that, in order to understand general patterns, habitat use must 
be analyzed at multiple scales (Thrush et al. 2005). Previous authors have noted that there is no single correct scale at which to quantify the spatial distribution of populations and have suggested that habitat use must be examined on multiple scales (Wiens 1989, Levin 1992). Recently, the importance of scale in the interpretation of spatial distribution of aquatic organisms has been noted (Essington \& Kitchell 1999, Maury et al. 2001, Pittman et al. 2004). Essington \& Kitchell (1999) showed telemetered largemouth bass distributions in a small Michigan lake were the product of several processes operating at spatial scales of 10,30 , and $180 \mathrm{~m}$. The authors concluded that the small-scale aggregation may have been a response to patches of aquatic macrophytes, while large-scale variation was a response to selection of the eastern half of the lake, possibly due to warmer water temperatures. Research addressing the effect of scale has not been as common for estuaries as it has for other systems; estuarine research has mostly examined the spatial correlations of recruitment variability (Scharf 2000, Bacheler et al. 2008b, Manderson 2008) and the habitat effects of invasive species (Hunter et al. 2006).

\section{Assumptions of GAMs}

Our modeling approach had some limitations. The flexibility of GAMs allow them to fit observed data very well, but sometimes that flexibility comes at the expense of generality (Jensen et al. 2005). In our study, the age-dependent habitat use patterns of red drum were often consistent across regions and years, suggesting that the patterns we observed were robust and not subject to overfitting. Our correlational approach could also not account for the effects of the spatial arrangement of habitat types, which in some cases has been found to be important (e.g. Essington \& Kitchell 1999).

\section{Management implications}

Detailed information on how organisms respond to abiotic and biotic factors will improve the ability of management agencies to delineate strategic habitats (Beck et al. 2001, Minello et al. 2003). For subadult red drum, this was a central recommendation of the fishery management plan in North Carolina. For instance, seagrasses appear to be important for age-1 and age-2 red drum behind the Outer Banks; loss of seagrass here due to shoreline development or reduced water quality conditions may negatively influence red drum in this region. The positive relationship we observed between telemetered red drum in Hancock Creek and dissolved oxygen concentrations also suggests the species is sensitive to water quality in estuarine creeks, so efforts to reduce nutrient loadings will have benefits for red drum. Most importantly, our results highlight the regional dependency of habitat use of red drum in North Carolina and suggest additional research may be required to determine the applicability of our findings to other locations.

GAMs have been useful for designating management areas for other estuarine organisms such as blue crab (Jensen et al. 2005) and spotted seatrout Cynoscion nebulosus (Kupschus 2003). Results from our study could similarly be useful in management of red drum. For example, given the strong influence of depth and distance from shore on subadult red drum distribution, regulations that limit fishing in shallow, nearshore waters could be developed if commercial or recreational discarding was a concern for fishery managers.

Acknowledgements. Funding for field work, data collection, and analyses was supported by Wallop-Breaux, NC Sea Grant (\#R/MRD-48 and R/MRD-52), and NC Beautiful. We thank S. Burdick, J. Edwards, M. Fox, M. May, W. Mitchell, and J. Morley for field work, and T. Ellis, K. Pollock, J. Gilliam, L. Daniel, and 3 anonymous reviewers for comments on earlier drafts of this manuscript. Reference to trade names does not imply endorsement by the US Government.

\section{LITERATURE CITED}

Adams DH, Tremain DM (2000) Association of large juvenile red drum, Sciaenops ocellatus, with an estuarine creek on the Atlantic coast of Florida. Environ Biol Fishes 58: 183-194

Alofs KM, Polivka KM (2004) Microhabitat-scale influences of resources and refuge on habitat selection by an estuarine opportunist fish. Mar Ecol Prog Ser 271:297-306

ASMFC (2007) Habitat program five-year strategic and management plan 2007-2011. Atlantic States Marine Fisheries Commission, Washington, DC

Bacheler NM (2008) Factors influencing the mortality and distribution of subadult red drum in North Carolina. PhD thesis, North Carolina State University, Raleigh, NC

Bacheler NM, Hightower JE, Paramore LM, Buckel JA, Pollock KH (2008a) An age-dependent tag return model for estimating mortality and selectivity of an estuarinedependent fish with high rates of catch and release. Trans Am Fish Soc 137:1422-1432

Bacheler NM, Paramore LM, Buckel JA, Scharf FS (2008b) Recruitment of juvenile red drum in North Carolina: spatiotemporal patterns of year-class strength and validation of a seine survey. N Am J Fish Manage 28:1086-1098

Baltz DM, Jones RF (2003) Temporal and spatial patterns of microhabitat use by fishes and decapod crustaceans in a Louisiana estuary. Trans Am Fish Soc 132:662-678

Barletta M, Barletta-Bergen A, Saint-Paul U, Hubold G (2005) The role of salinity in structuring the fish assemblages in a tropical estuary. J Fish Biol 66:45-72

Beck MW, Heck KL, Able KW, Childers DL and others (2001) The identification, conservation, and management of estu- 
arine and marine nurseries for fish and invertebrates. BioScience 51:633-641

Bell GW, Eggleston DB, Wolcott TG (2003) Behavioral responses of free-ranging blue crabs to episodic hypoxia. I. Movement. Mar Ecol Prog Ser 259:215-225

Benaka L (1999) Fish habitat: essential fish habitat and rehabilitation. Am Fish Soc Symp 22, Bethesda, MD

Buckley J (1984) Habitat suitability index models: larval and juvenile red drum. FWS/OBS-82/10.74, US Fish and Wildlife Service, Washington, DC

Burnham KP, Anderson DR (2002) Model selection and inference: a practical information-theoretic approach, 2nd edn. Springer-Verlag, New York

> Collins MR, Smith TIJ, Jenkins WE, Denson MR (2002) Small marine reserves may increase escapement of red drum. Fisheries 27:20-24

Cooke SJ, Hinch SG, Wikelski M, Andrews RD, Wolcott TG, Butler PJ (2004) Biotelemetry: a mechanistic approach to ecology. Trends Ecol Evol 19:334-343

Craig JK, Crowder LB (2000) Factors influencing habitat selection in fishes with a review of marsh ecosystems. In: Weinstein MP, Kreeger DA (eds) Concepts and controversies in tidal marsh ecology. Kluwer Academic Publishers, Dordrecht, p 241-266

> Crossman EJ, Hamilton JG (1978) An apparatus for sampling gut contents of large, living fishes. Environ Biol Fishes 3: 297-300

Dahlgren CP, Kellison GT, Adams AJ, Gillanders BM and others (2006) Marine nurseries and effective juvenile habitats: concepts and applications. Mar Ecol Prog Ser 312:291-295

Dresser BK (2003) Habitat use and movement of subadult red drum, Sciaenops ocellatus, within a salt marsh-estuarine system. MSc thesis, University of Georgia, Athens, GA

$>$ Dresser BK, Kneib RT (2007) Site fidelity and movement patterns of wild subadult red drum, Sciaenops ocellatus (Linnaeus), within a salt marsh-dominated estuarine landscape. Fish Manag Ecol 14:183-190

> Eby LA, Crowder LB (2002) Hypoxia-based habitat compression in the Neuse River Estuary: context-dependent shifts in behavioral avoidance thresholds. Can J Fish Aquat Sci 59:952-965

Essington TE, Kitchell JF (1999) New perspectives in the analysis of fish distributions: a case study on the spatial distribution of largemouth bass (Micropterus salmoides). Can J Fish Aquat Sci 56(Suppl 1):52-60

Fagan WF, Aumann C, Kennedy CM, Unmack PJ (2005) Rarity, fragmentation, and the scale dependence of extinction risk in desert fishes. Ecology 86:34-41

Gannon DP (2003) Behavioral ecology of an acoustically mediated predator-prey system: bottlenose dolphins and sciaenid fishes. PhD thesis, Duke University, Durham, NC

Gilliam JF, Fraser DF (1987) Habitat selection under predation hazard: test of a model with foraging minnows. Ecology 68:1856-1862

Hastie TJ, Tibshirani RJ (1990) Generalized additive models. Chapman \& Hall, London

Heck KL Jr, Hays G, Orth RJ (2003) Critical evaluation of the nursery role hypothesis for seagrass meadows. Mar Ecol Prog Ser 253:123-136

Holt SA, Kitting CL, Arnold CR (1983) Distribution of young red drums among different sea-grass meadows. Trans Am Fish Soc 112:267-271

Hunter KL, Fox DA, Brown LM, Able KW (2006) Responses of resident marsh fishes to stages of Phragmites australis invasion in three mid-Atlantic estuaries. Estuaries Coasts 29:487-498
Ives AR, Kareiva P, Perry R (1993) Response of a predator to variation in prey density at three hierarchical scales: lady beetles feeding on aphids. Ecology 74:1929-1938

Jensen OP, Seppelt R, Miller TJ, Bauer LJ (2005) Winter distribution of blue crab Callinectes sapidus in Chesapeake Bay: application and cross-validation of a two-stage generalized additive model. Mar Ecol Prog Ser 299:239-255

Kennard MJ, Olden JD, Arthington AH, Pusey BJ, Poff NL (2007) Multiscale effects of flow regime and habitat and their interaction on fish assemblage structure in eastern Australia. Can J Fish Aquat Sci 64:1346-1359

Krebs C (1989) Ecological methodology. Harper Collins, New York

Kupschus S (2003) Development and evaluation of statistical habitat suitability models: an example based on juvenile spotted seatrout Cynoscion nebulosus. Mar Ecol Prog Ser 265:197-212

- Levin SA (1992) The problem of pattern and scale in ecology. Ecology 73:1943-1967

> Manderson JP (2008) The spatial scale of phase synchrony in winter flounder (Pseudopleuronectes americanus) production increased among southern New England nurseries in the 1990s. Can J Fish Aquat Sci 65:340-351

- Maury O, Gascuel D, Marsac F, Fonteneau A, De Rosa AL (2001) Heirarchical interpretation of nonlinear relationships linking yellowfin tuna (Thunnus albacares) distribution to the environment in the Atlantic Ocean. Can J Fish Aquat Sci 58:458-469

> McIvor CC, Odum WE (1988) Food, predation risk, and microhabitat selection in a marsh fish assemblage. Ecology 69: 1341-1351

Miltner RJ, Ross SW, Posey MH (1995) Influence of food and predation on the depth distribution of juvenile spot (Leiostomus xanthurus) in tidal nurseries. Can J Fish Aquat Sci 52:971-982

> Minello TJ, Able KW, Weinstein MP, Hays CG (2003) Salt marshes as nurseries for nekton: testing hypotheses on density, growth and survival through meta-analysis. Mar Ecol Prog Ser 246:39-59

Morris L, Ball D (2006) Habitat suitability modeling of economically important fish species with commercial fisheries data. ICES J Mar Sci 63:1590-1603

Pietrafesa LJ, Janowitz GS (1991) The Albemarle Pamlico coupling study. Report No. 90-13, Albemarle Pamlico Estuarine Study, Raleigh, NC

Pietrafesa LJ, Janowitz GS, Miller JM, Noble EB, Ross SW, Epperly SP (1986) Abiotic factors influencing the spatial and temporal variability of juvenile fish in Pamlico Sound, North Carolina. In: Wolfe DA (ed) Estuarine variability. Academic Press, London, p 341-352

Pihl L, Baden SP, Diaz RJ (1991) Effects of periodic hypoxia on distribution of demersal fish and crustaceans. Mar Biol 108:349-360

Pittman SJ, McAlpine CA, Pittman KM (2004) Linking fish and prawns to their environment: a hierarchical landscape approach. Mar Ecol Prog Ser 283:233-254

> Procarione LS, King TL (1993) Upper and lower temperature tolerance limits for juvenile red drums from Texas and South Carolina. J Aquat Anim Health 5:208-212

Reagan RE Jr (1985) Species profiles: life histories and environmental requirements of coastal fishes and invertebrates (Gulf of Mexico) - red drum. Biological Report 82(11.36), US Fish and Wildlife Service, Washington, DC

> Rooker JR, Holt SA (1997) Utilization of subtropical seagrass meadows by newly settled red drum Sciaenops ocellatus: patterns of distribution and growth. Mar Ecol Prog Ser 158:139-149 
Rooker JR, Holt SA, Soto MA, Holt GJ (1998) Postsettlement patterns of habitat use by sciaenid fishes in subtropical seagrass meadows. Estuaries 21:318-327

Rose GA, Leggett WC (1990) The importance of scale to predator-prey spatial correlations: an example of Atlantic fishes. Ecology 71:33-43

Ross SW, Epperly SP (1986) Utilization of shallow estuarine nursery areas by fishes: Pamlico Sound adjacent tributaries, North Carolina. In: Yanez-Arancibbia A (ed) Fish community ecology in estuaries and coastal lagoons: towards an ecosystem integration. UNAM Press, Mexico City, p 207-232

Ross JL, Stevens TM, Vaughan DS (1995) Age, growth, mortality, and reproductive biology of red drums in North Carolina waters. Trans Am Fish Soc 124:37-54

Rozas LP, Minello TJ (1997) Estimating densities of small fishes and decapod crustaceans in shallow estuarine habitats: a review of sampling design with focus on gear selection. Estuaries 20:199-213

Ruiz GM, Hines AH, Posey MH (1993) Shallow water as a refuge habitat for fish and crustaceans in non-vegetated estuaries: an example from Chesapeake Bay. Mar Ecol Prog Ser 99:1-16

Scharf FS (2000) Patterns in abundance, growth, and mortality of juvenile red drum across estuaries on the Texas coast with implications for recruitment and stock enhancement. Trans Am Fish Soc 129:1207-1222

Scharf FS, Schlicht KK (2000) Feeding habits of red drum (Sciaenops ocellatus) in Galveston Bay, Texas: seasonal diet variation and predator-prey size relationships. Estuaries 23:128-139

Schneider DS (2001) The rise of the concept of scale in ecology. BioScience 51:545-553

Shriner SA, Wilson KR, Flather CH (2006) Reserve networks based on richness hotspots and representation vary with scale. Ecol Appl 16:1660-1673

Stewart RR, Noyce T, Possingham HP (2003) Opportunity cost of ad hoc marine reserve design decisions: an example from South Australia. Mar Ecol Prog Ser 253:25-38

Stoner AW, Manderson JP, Pessutti JP (2001) Spatially explicit analysis of estuarine habitat for juvenile winter flounder: combining generalized additive models and geographic

Editorial responsibility: Jana Davis,

Annapolis, Maryland, USA information systems. Mar Ecol Prog Ser 213:253-271

Street MW, Deaton AS, Chappell WS, Mooreside PD (2005) North Carolina Coastal Habitat Protection Plan. North Carolina Division of Marine Fisheries, Morehead City, NC Stunz GW, Minello TJ, Levin PS (2002) A comparison of early juvenile red drum densities among various habitat types in Galveston Bay, Texas. Estuaries 25:76-85

Sutton TM, Cyterski MJ, Ney JJ, Duval MC (2004) Determination of factors influencing stomach-content retention by striped bass captured using gill nets. J Fish Biol 64: 903-910

Swartzman G, Huang G, Kaluzny S (1992) Spatial analysis of Bering Sea groundfish survey data using generalized additive models. Can J Fish Aquat Sci 49:1366-1378

Takade HM, Paramore LM (2007) Stock status of the northern red drum stock. North Carolina Division of Marine Fisheries, Morehead City, NC

> Thrush SF, Hewitt JE, Herman PMJ, Ysebaert T (2005) Multiscale anaysis of species-environment relationships. Mar Ecol Prog Ser 302:13-26

Venables WN, Ripley BD (1999) Modern applied statistics with S-PLUS, 3rd edn. Springer-Verlag, New York

> Waters DS, Kwak TJ, Arnott JB, Pine WE III (2004) Evaluation of stomach tubes and gastric lavage for sampling diets from blue catfish and flathead catfish. N Am J Fish Manage 24:258-261

> Wiens JA (1989) Spatial scaling in ecology. Funct Ecol 3: 385-397

Wenner C (1992) Red drum: natural history and fishing techniques in South Carolina. South Carolina Marine Resources Research Institute, Educational Report No. 17, Charleston, SC

White JW, Warner RR (2007) Safety in numbers and the spatial scaling of density-dependent mortality in a coral reef fish. Ecology 88:3044-3054

Whitfield AK (1996) A review of factors influencing fish utilization of South African estuaries. Trans R Soc S Afr 51: 115-137

> Wilson HF, Xenopoulos MA (2008) Landscape influences on stream fish assemblages across spatial scales in a northern Great Plains ecoregion. Can J Fish Aquat Sci 65: $245-257$

Submitted: January 4, 2008; Accepted: October 28, 2008 Proofs received from author(s): February 6, 2009 